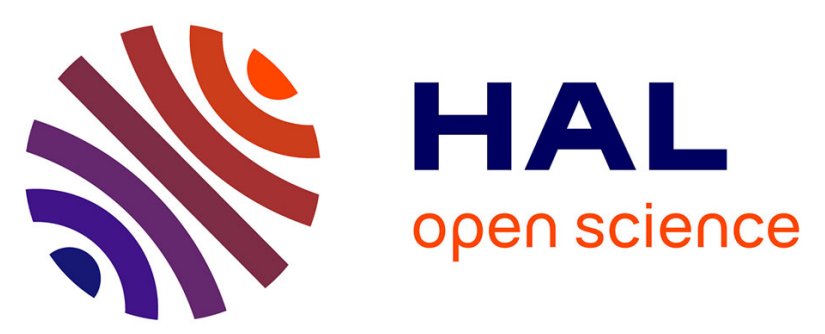

\title{
Complement activation during intravascular hemolysis: implication for sickle cell disease and hemolytic transfusion reactions
}

Nicolas Merle, Idris Boudhabhay, Juliette Leon, V. Fremeaux-Bacchi, Lubka Roumenina

\section{To cite this version:}

Nicolas Merle, Idris Boudhabhay, Juliette Leon, V. Fremeaux-Bacchi, Lubka Roumenina. Complement activation during intravascular hemolysis: implication for sickle cell disease and hemolytic transfusion reactions. Transfusion Medicine Reviews, 2019, 26 (2), pp.116-124. 10.1016/j.tracli.2019.02.008 . hal-02479719

\section{HAL Id: hal-02479719 \\ https://hal.sorbonne-universite.fr/hal-02479719}

Submitted on 14 Feb 2020

HAL is a multi-disciplinary open access archive for the deposit and dissemination of scientific research documents, whether they are published or not. The documents may come from teaching and research institutions in France or abroad, or from public or private research centers.
L'archive ouverte pluridisciplinaire HAL, est destinée au dépôt et à la diffusion de documents scientifiques de niveau recherche, publiés ou non, émanant des établissements d'enseignement et de recherche français ou étrangers, des laboratoires publics ou privés. 
Complement activation during intravascular hemolysis: implication for sickle cell disease and hemolytic transfusion reactions

Nicolas S. Merle ${ }^{1}$, Idris Boudhabhay ${ }^{1}$, Juliette Leon ${ }^{1}$, Véronique Frémeaux Bacchi ${ }^{1,2}$, Lubka T. Roumenina ${ }^{1, *}$

${ }^{1}$ Centre de Recherche des Cordeliers, INSERM, Sorbonne Université, USPC, Université Paris Descartes, Université Paris Diderot, F-75006 Paris, France

${ }^{2}$ Service d'Immunologie Biologique, Hôpital Européen Georges Pompidou, Assistance Publique Hôpitaux de Paris, Paris, France

* Correspondence to: Lubka T. Roumenina, Ph.D.

Cordeliers Research Center, INSERM UMRS 1138;

15 rue de l'Ecole de Médecine; 75006 Paris, France

Phone: +33-1-44-27-90-96/ Fax: +33-1-40-51-04-20,

e-mail: 1ubka.roumenina@crc.jussieu.fr 


\begin{abstract}
Intravascular hemolysis is a hallmark of a large spectrum of diseases, including the sickle cell disease (SCD), and is characterized by liberation of red blood cell (RBC) degradation products in the circulation. Released $\mathrm{Hb}$, heme, $\mathrm{RBC}$ fragments and microvesicles (MVs) exert pro-inflammatory, pro-oxidative and cytotoxic effects and contribute to vascular and tissue damage. The innate immune complement system not only contributes to the RBC lysis, but it is also itself activated by heme, RBC MVs and the hypoxia-altered endothelium, amplifying thus the cell and tissue damage. This review focuses on the implication of the complement system in hemolysis and hemolysis-mediated injuries in SCD and in cases of delayed hemolytic transfusion reactions (DHTR). We summarize the evidences for presence of biomarkers of complement activation in patients with SCD and the mechanisms of complement activation in DHTR. We discuss the role of antibodies-dependent activation of the classical complement pathway as well as the heme-dependent activation of the alternative pathway. Finally, we describe the available evidences for the efficacy of therapeutic blockade of complement in cases of DHTR. In conclusion, complement blockade is holding promises but future prospective studies are required to introduce Eculizumab or another upcoming complement therapeutic for DHTR and even in SCD.
\end{abstract}




\section{Résumé}

L'hémolyse intra-vasculaire est la conséquence d'un grand nombre de maladies, dont la drépanocytose, caractérisée par la libération de produits de dégradation des Globules Rouges (GR) dans la circulation. L'hémoglobine, l'hème, les fragments de GR et les MicroVésicules (MV) libérées ont une action pro-inflammatoire et pro-oxydative, exercent des effets cytotoxiques, et contribuent aux dommages vasculaires et tissulaires. Le système du complément contribue à la lyse des GR. Il est lui-même activé par l'hème, les MV et l'endothélium lésé par l'hypoxie, amplifiant ainsi les dommages cellulaires et tissulaires. Dans cette revue, nous détaillons l'implication du système du complément dans l'hémolyse ainsi que ses conséquences dans la drépanocytose et l'hémolyse post-transfusionnelle retardée (HPTR). Nous résumons les preuves existantes de l'activation du complément dans les modèles murins et chez l'Homme. Par ailleurs, nous discutons le rôle des anticorps dans l'activation de la voie classique du complément, parallèlement à l'activation de la voie alterne par l'hème. Enfin, nous décrivons les preuves actuelles de l'efficacité des thérapeutiques bloquant le complément dans l'HPTR. En conclusion, le système du complément apparait comme un acteur clé, jusqu'à lors sous-estimé, de la physiopathologie de l'HPRT et de la drépanocytose, ouvrant la voie à de nouvelles thérapeutiques prometteuses. 


\section{Introduction}

Intravascular hemolysis is a characteristic of a large set of diseases, having different etiologies (1). Key examples include: 1) intravascular hemolysis due to genetic alterations, like mutations in the hemoglobin $(\mathrm{Hb})$ gene in Sickle Cell Disease (SCD), or 2) due to immune-mediated causes, as the destruction of the Red Blood Cells (RBC) related to activation of the complement system in the Hemolytic Transfusion Reactions (HTR), where patients develop antibodies against transfused RBC antigens 3) or due to infections, like malaria. The destruction of the RBC in the circulation leads to the release of $\mathrm{Hb}$ and heme. In physiological conditions, $\mathrm{Hb}$ is rapidly bound to Haptoblogin ( $\mathrm{Hp}$ ) and heme to Hemopexin $(\mathrm{Hx})$, resulting in scavenging and removal from blood $(2,3)$. However, in these pathological conditions, both scavengers are consumed, and large amount of hemolysis derived products are released. Once in the circulation, $\mathrm{Hb}$, heme, the $\mathrm{RBC}$ fragments and microvesicles (MVs) exert pro-inflammatory, pro-oxidative and cytotoxic effects and contribute to vascular and tissue damage (4-6). The innate immune complement system not only contributes to the RBC lysis, but it is also itself activated by heme, RBC MV and the hypoxia-altered endothelium, amplifying the cell and tissue damage (5). This review focuses on the implication of the complement system in hemolysis and hemolysis-mediated injuries in SCD and in the cases of HTR.

\section{The complement system}

The complement system constitutes a sophisticated effector of the innate immunity (7). It is a sentinel, helping to fight infections and contributing to the maintenance of the homeostasis. Nevertheless, when overactivated in pathological conditions, it promotes organ damage and it is a key mediator of inflammation. Namely this misdirected and abnormal activation, which occurs on the RBC or which is mediated by the RBC-derived products, plays a role in the pathological process in SCD and HTR.

Complement is a cascade of three pathways - classical, lectin, and alternative, each distinguished by its initiation mechanism (8). The integrated complement system overall contains more than 50 components. They form an elaborate network of fluid-phase, cell surface-associated, and intracellular proteins, which function as pattern-recognition molecules, proteases/convertases, regulators, or signaling receptors, collectively mediating immune surveillance and tissue homeostasis (9). Traditionally, this cascade is considered to "complement" the ability of antibodies and phagocytes to clear microorganisms via $\mathrm{C} 3 \mathrm{~b}$ opsonization (10). It promotes inflammation via the anaphylatoxins C3a and C5a (11) and lyses pathogens via the C5b-9 Membrane-Attack-Complex (MAC) (12). Further, complement mediates the clearance of immune complexes and apoptotic cells, contributes to normal tissue development and promotes tissue repair after injury (13). Likewise, complement 
provides a link between innate and adaptive immunity $(14,15)$ and develops cross-talks with endothelial cells and coagulation system (16).

The classical pathway can be activated by a multitude of ligands recognized by C1q, such as immune complexes on pathogen surface $(17,18)$. The lectin pathway is activated following recognition of mannose-containing glycans by recognition molecules, such as Mannose-Binding Lectin (19). Conversely, the alternative pathway is permanently activated at low level by spontaneous hydrolysis of $\mathrm{C} 3$ in bioactive $\mathrm{C} 3\left(\mathrm{H}_{2} \mathrm{O}\right)(20)$. This mechanism, known as "tick-over", allows rapid response against pathogens. The three pathways converge to the formation of classical and alternative $\mathrm{C} 3$ Convertases that cleave $\mathrm{C} 3$ in $\mathrm{C} 3 \mathrm{a}$ and $\mathrm{C} 3 \mathrm{~b}$. Then, $\mathrm{C} 3 \mathrm{~b}$ can be used to form new $\mathrm{C} 3$ convertase, creating an amplification loop. Finally, the terminal pathway is common with the formation of the MAC that forms pores in the target membrane (8) (Figure 1). C3b can bind to cell surfaces thanks to its thioester bond but also via several surface molecules acting as "platforms". For example, properdin expressed by activated neutrophils or bound to platelets, recruits $\mathrm{C} 3 \mathrm{~b}$ and promotes $\mathrm{C} 3$ convertase formation in addition to its stabilization $(21,22)$. Likewise, P-selectin expressed by activated endothelial cells has also been described to act as a platform for $\mathrm{C} 3$ convertase formation $(23,24)$.

Under physiological conditions, activation of the complement system is tightly regulated thanks to several proteins in fluid phase and on host cells (25) (Figure 1). Plasmatic regulators include Factor I (FI). This serine protease regulates all pathways by cleaving $\mathrm{C} 3 \mathrm{~b}$ and $\mathrm{C} 4 \mathrm{~b}$ (26). Its activity requires the presence of cofactors such as Factor H (FH), Membrane Cofactor Protein (MCP), Complement Receptor 1 (CR1) or $\mathrm{C} 4$ Binding Protein (C4BP). Among them, FH represents the main regulator of the alternative pathway thanks to three regulatory functions: dissociation of the alternative $\mathrm{C} 3$ convertase, prevention of its formation, and cofactor activity (27, 28). Membrane regulation is assumed by MCP (CD46), which binds $\mathrm{C} 3 \mathrm{~b}$ and $\mathrm{C} 4 \mathrm{~b}$ in addition to its cofactor activity while Decay Accelerating Factor (DAF) acts by biding to $\mathrm{C} 3 \mathrm{~b}$ and accelerates dissociation of both $\mathrm{C} 3$ and $\mathrm{C} 5$ convertase (29). MAC is also tightly regulated: C5b9 formation is inhibited in fluid phase by vitronectin and clusterin, while CD59, a GPI-anchored protein, blocks membrane perforation by C5b$9(25)$.

Both inefficient and excessive activation of the complement system can lead to a multitude of disorders (30) including increased susceptibility to infections (31), inflammatory/auto-immune diseases (32-37), age-related diseases $(38,39)$ and cancer $(40)$. Recent studies revived the interest towards the old concept that complement can be activated in and contributes to the pathological process in SCD. The context becomes even more complex in case of HTR, when complement contributes as a cause and as a consequence of the RBC lysis. 


\section{SCD and complement}

SCD is a single gene disorder characterized by mutant hemoglobin-S, causing wide variety of symptoms $(41,42)$. The chronic intra-vascular hemolysis is a hallmark of this disease and leads to overload of the scavenging systems (43). As a result, SCD patients show high levels of hemoglobin, labile heme and heme loaded RBC MVs, which are known to contribute to endothelial cells damage and vaso-occlusions (44-46).

Even if activation of the complement system in SCD is known since the 70's (47), the link with hemolysis has been overall poorly studied. Early reports showed that SCD patients in crisis exhibited increased complement activation markers such as $\mathrm{Bb}$ and sC5b-9 in plasma, compared with the baseline and with healthy donors (48). More recently, increased sC5b-9 was mentioned in two independent SCD cohorts, compared to controls $(49,50)$ and C5a increase in another one (51). An in vitro test for complement-mediated cell killing (so called modified Ham test), was positive in 5/34 SCD patients and the cell death was prevented by $\mathrm{C} 5$ blockade by the therapeutic anti-C5 antibody Eculizumab (49). Furthermore, RBC from SCD patients in crisis or even in remission displayed increased levels of surface-bound C3 fragments $(48,51,52)$ and activated the alternative pathway more than control RBC in an in vitro system (48). These observations lead to three important conclusions: (1) complement is activated in vivo in SCD; (2) complement might play a role in the sickle RBC destruction itself, unrelated to IgG-related process; (3) RBC from SCD patients are able to activate the alternative pathway and are more sensitive to complement system activation than control RBC.

With regard to tissue injuries in SCD patients, the role of complement has been poorly described. The first observation dates from 1975. One SCD patient diagnosed with glomerulonephritis presented renal complement activation, presumably IgG-mediated via the classical pathway (53). Subsequently, few reports have mentioned C3 fragments deposition in kidneys in humans and in a mouse model of $\operatorname{SCD}(54,55)$. More recently, Merle et al. demonstrated the presence of tissue deposits of C3 activation fragments and C5b-9 in kidney biopsies of SCD nephropathy patients and in kidneys of two mouse models of SCD - HbSS Townes and SAD (56). Further, Vercellotti et al., confirmed and extended the notion that complement contributes to the tissue injury in SCD. They showed that at baseline but also after hypoxia/reoxygenation, HbSS Townes mice had increased C3 fragments and C5b-9 deposition in kidneys, livers and lungs. Moreover, Lombardi et al described microvascular deposition of C5b-9 on skin biopsies from SCD patients (51). Increased level of alternative pathway fragment $\mathrm{Bb}$ was also found in the plasma of HbSS Townes mice (57). Injection of complement anaphylatoxin C5a provoked vaso-occlusion in HbSS Townes. Finally, blockade of C5 cleavage or $\mathrm{C} 5 \mathrm{aR}$ in the context of hypoxia/reoxygenation prevented the vaso-occlusion in these mice. 
Little is known on the contribution of complement regulators as modulators of the SCD disease process. C3b-opsinized SCD RBC adhere to activated endothelial cells in vitro, adopting a peculiar stop-and-go motion (51). The $\mathrm{C} 3 \mathrm{~b}$ regulator Factor $\mathrm{H}$ prevented the adhesion of sickle red cells to the endothelium, normalizing speed transition times. Although no data is available for the expression of the membrane complement regulators and anaphylatoxin receptors on patients' endothelium, in vitro experiments showed that heme-exposed endothelium decreases the expression of CD46 and CD55 and upregulation of C3aR and C5aR $(56,58-60)$.

The activation of complement in vivo in the context of SCD is a multifactorial process, dependent on the endothelial alteration after hypoxia (57) and on the intravascular hemolysis. In mouse models, Merle et al. and May et al. demonstrated that intravascular hemolysis induced heme-dependent complement deposits in tissues, including kidneys and endothelium, which contributed to the organ injury $(56,59,60)$. This is in agreement with in vitro data showing that alternative pathways can be activated by heme and heme-injured endothelium $(58,60,61)$. Therefore, complement and hemolysis could synergize to promote endothelial activation and renal or liver injury $(60,62,63)$. Better understanding the link between activation of complement system and hemolysis could help treating many complications of SCD. Among them, Delayed-Hemolytic Transfusion Reactions (DHTRs) represent a key example.

\section{Delayed-Hemolytic Transfusion Reactions and complement}

DHTR is defined as immune-mediated hemolysis of allogeneic donor RBC, which occurs in patients who have been alloimmunized previously. These are well-recognized severe complications of blood transfusion (64). Indeed, RBC transfusions remain a very important modality of treatment for patients with SCD (65), with a majority (60-90\%) of patients receiving RBC transfusions in their lifetime (66). Despite the benefits of transfusion, approximately $20-50 \%$ of patients with SCD develop antibodies against alloantigen on transfused RBC (66), with an increased risk of DHTR (67). In this case, despite an extensive screening before transfusion, the irregular alloantibody titers have fallen below serologically detectable levels by the direct antiglobulin test (DAT) (68). DHTR is classically caused by a secondary immune reaction where alloantibodies undetectable at the time of transfusion rebound following exposure to the corresponding RBC antigens, leading to the RBC destruction.

DHTR occurs between 3 and 22 days after RBC transfusion (69), in around 3-8\% of transfused SCD patients (70-72), which in $4-12 \%$ of DHTR can be fatal $(69,71,73,74)$. It remains poorly recognized, mostly because it mimics an acute painful crisis. Symptoms of DHTR typically include generalized pain, fever, hemoglobinuria, renal failure, and a drop in total $\mathrm{Hb}$ and $\mathrm{Hb} \mathrm{A}$ from the post-transfusion 
value (69). This severe reaction is most likely promoted by damage to the underlying vasculature by released free $\mathrm{Hb}$ and heme (75).

The mechanism of anemia that occurs following $\mathrm{RBC}$ transfusion remains controversial. Using $\mathrm{Hb}$ electrophoresis, it is evident that donor RBC are destroyed during DHTR, but in some cases the recipient's own RBC are lysed as well. The lysis of the donor's RBC can be easily explained, when antibodies directed against the transfused units are detected. However, alloantibodies may not be detected at the time of the DHTR, may become detected later, or may never be detected (76).

Complement plays a key role in the RBC destruction in DHTR, due to activation of the classical complement pathway on RBC-bound antibodies (77) and the possibility of alternative pathway activation on the RBC surface by the exposure of PS and by the action of heme $(52,58,61)$. Moreover, the efficiency of anti-complement therapy has recently highlighted its crucial role, both in immune-mediated hemolysis and in organ injuries (78-80).

The IgG antibodies, leading to DHTR, might belong to two different types: complement fixing (with different degrees of engagement) and non-complement fixing (77). When a non-complement binding IgG is involved, the extravascular reticuloendothelial cell-mediated mechanisms of RBC destruction will take place. Complement fixing antibodies activate the classical pathway. In such case, either the activation is complete, leading to MAC formation and direct intravascular lysis, or incomplete, resulting in opsonization with $\mathrm{C} 3$ activation fragments $(\mathrm{C} 3 \mathrm{~d}+)$ and extravascular hemolysis, due to phagocytosis (Figure 2). The role of the classical pathway is supported by the fact that these donorcoated RBC have a longer survival in vivo in $\mathrm{C} 2$ - and $\mathrm{C} 4$-deficient recipients. As polyclonal antibodies typically mediate DHTR, the unique composition and affinity of the recipient antibodies panel and the type of antigens will impact the degree of complement involvement in the pathogeny (77). Interestingly, in several cases of DHTR, no alloantibodies were detected and the DAT was negative. These observations have increased the potential role of the alternative complement pathway in DHTR $(79,81-83)$. Since these cases are often associated with hyperhemolysis, it is likely that heme release plays a key role in complement overactivation.

\section{Potential mechanisms of complement activation in case of intravascular hemolysis, relevant for SCD and DHTR}

To propose better treatment for SCD and DHTR, detailed knowledge of their pathophysiology is required. Further studies are needed to explain why in some cases the presence of antibodies is associated with DHTR and in others - no. Why in some cases there is a classical complement pathway activation and in others - no. What is the contribution of the alternative complement pathway? How complement overactivation contributes to vaso-occlusion and to organ injury? 
Although no firm answer could be given today, data from different experimental models allow to propose few hypotheses.

\section{Different antibodies - different consequences}

Limited data is available for the exact affinity and binding properties of the antibodies, causing DHTR in SCD. Studies of the affinity and the off-rate of the antibodies as well as the distribution of their antigens could provide clues about their capacity to cause RBC destruction. The affinity is a ratio between the dissociation rate (off-rate) and the association rate. Even if an antibody binds with a high affinity to its antigen on the RBC surface, it will not be efficient in engaging Fc receptors or complement if it dissociates fast. Recent studies, though in different context, demonstrated that the disposition of the antigens on the surface, their density and distance from the membrane affect the recognition by the $\mathrm{Fc}$ receptors and $\mathrm{C} 1 \mathrm{q}$. The thermodynamic stability of the antibodies and the density of the antigens affect the binding kinetic and complex stability $(84,85)$. Naturally occurring polyreactive antibodies are less likely to play a role in DHTR-related RBC destruction, due to the delay of the reaction. Nevertheless, in case of ongoing intravascular hemolysis, heme and Fe ions could be released $(5,86)$. These molecules could bind to immunoglobulins, inducing polyspecificity $(87,88,89,90)$. If such antibodies acquire the capacity to bind to $\mathrm{RBC}$, they could contribute to accelerate the lysis.

Specific noncovalent interactions between Fc segments of $\mathrm{IgG}$ result in the formation of ordered antibody hexamers after antigen binding on cells $(91,92)$. These hexamers recruit and activate $\mathrm{C} 1$, and trigger the complement, similarly to IgM, which is a pentamer or hexamer on its own and has a stronger ability to recruit $\mathrm{C} 1$. Moreover, only $\operatorname{IgG} 1$ and $\operatorname{IgG} 3$ activate strongly complement.

Murine models of immunity directed against RBC antigens as well as models of antibody mediated hemolysis have been developed (93). Briefly, these transgenic mice models express clinically significant transgenic human antigens at the erythrocyte membrane (e.g. human glycophorin A (94) or non-human antigens (e.g. hen egg lysozyme (HEL)(95), or a combination of both (e.g the HOD mice displaying transgenic RBC specific expression of HEL, ovalbumine, and Duffy b (96, 97). Since most of the mouse models have focused on studying the mechanisms of post-transfusion alloimmunization (98), the role of complement has not been extensively described. Certain reports have uncovered indirectly some evidence of complement involvement, such as a rapid complement-mediated intravascular hemolysis related to IgM passive immunization (94), different levels of complementmediated RBC clearance depending of the IgG sub-classes (94), or the C3 involvement in apparent antigen modulation of RBC (99). 


\section{Particular sensitivity of the sickle RBC to complement attack}

It has been suggested that sickle RBC are more sensitive to complement attack. Wang et al. showed that deoxygenation of erythrocytes from SCD patients increases membrane phospholipid exposure (phosphatidylethanolamine, PE and phosphatidylserine, PS) on the outer membrane (52). This exposure induces alternative complement pathway activation in vitro. Later, Test et al. reported that RBC from SCD patients show a defect in the regulation of MAC formation, with increased binding of $\mathrm{C} 5 \mathrm{~b} 7$ and $\mathrm{C} 9$ and increased susceptibility to complement-mediated lysis, initiated with activated cobra venom factor (100). This might be explained by a loss of membrane glycosylphosphatidylinositolanchored complement regulatory proteins CD55 and CD59, due to the change in phospholipid exposure and the membrane distortion related to sickle $\mathrm{Hb}$ tactoid formation. Finally, a direct link between heme, which is released in the bloodstream during hemolysis, and alternative pathway activation has been demonstrated in vitro in malaria (61) and in atypical hemolytic uremic syndrome (58) models.

\section{Complement activation by cell-free heme}

In the last decade, in vitro investigations have enlightened the capacity of the end-stage product of hemolysis, heme, to interact with complement, both with the classical and alternative pathways (5). Heme directly binds to C1q, causing a change in the mechanism of recognition of CRP and $\operatorname{IgG}(89,101)$. First evidence of the interaction between heme and the alternative pathway has been provided in 2007, in a model of malaria (61). In this study, the authors demonstrated that heme activates complement alternative pathway by inducing $\mathrm{C} 3 \mathrm{~b}$ deposition on normal erythrocytes. CR1 erythrocytes expression correlated with $\mathrm{C} 3 \mathrm{dg}$ deposits and even CR1 was shown to be the platform for $\mathrm{C} 3 \mathrm{~b}$ deposition. The opsonization of the $\mathrm{RBC}$ with $\mathrm{C} 3 \mathrm{~d}$ could promote the clearance of these erythrocytes by CR2 expressing B cells in the spleen. These $\mathrm{C} 3 \mathrm{~b} / \mathrm{C} 3 \mathrm{~d}$ deposits and $\mathrm{RBC}$ lysis were efficiently inhibited by the C3b-binding peptide Cp40, derived from compstatin (102). More recently, we showed that heme induces alternative complement pathway activation directly in serum and on endothelial cells $(56,58)$, by promoting hydrolysis of $\mathrm{C} 3$ and formation of a fluid phase $\mathrm{C} 3$ convertase. $\mathrm{C} 3 \mathrm{a}, \mathrm{C} 5 \mathrm{a}$ and $\mathrm{sC} 5 \mathrm{~b} 9$ are detected in sera in a dose-dependent manner of heme concentration (Figure 3).

We have recently described a novel mechanism, by which heme promotes complement deposition on stressed endothelial cells, by recruitment of $\mathrm{C} 3 \mathrm{~b}$ and $\mathrm{C} 3(\mathrm{H} 2 \mathrm{O})$ via P-selectin binding (60). Heme functions as a ligand for TLR4 $(60,103-105)$. TLR4 activation by heme contributes to ROS induction and exocytosis of von Willebrand Factor and P-selectin through Weibel-Palade bodies mobilization by endothelial cells in vitro and in SCD mouse model $(46,60)$. P-selectin is an unconventional platform for $\mathrm{C} 3 \mathrm{~b}$ and $\mathrm{C} 3(\mathrm{H} 2 \mathrm{O})$ that could promote local complement activation $(23,24,60)$, thus 
bridging endothelial stress and complement under hemolytic conditions (60). In vivo experiments in a mouse model of intravascular hemolysis (106) revealed attenuation of the liver injury by C3 deficiency and C5 blockade (60). Moreover, P-selectin inhibition decreased complement deposits and signs of liver stress response. In an in vitro model of C3b-opsonized SCD RBC interaction with activated endothelial cells, the $\mathrm{C} 3 \mathrm{~b}$ regulator Factor $\mathrm{H}$ reduced adhesion of the $\mathrm{RBC}$ to endothelial $\mathrm{P}$ selectin (51). Since P-selectin targeting is now possible in clinical settings (107), it is tempting to speculate that this treatment will reduce complement activation on endothelium of patients with SCD, and therefore the complement-mediated endothelial lesions.

Heme-triggered complement activation was likely due to the alternative pathway activation, since in vitro experiments performed with FB-deficient sera completely abrogated complement activation in serum and on endothelial cells surface $(58,61)$. Taken together, these results point towards a hypothesis of a link between hemolysis and complement activation in the context of hemolytic conditions and diseases. To find out to what extend the complement activation can occur during hemolysis and what is the underlying mechanism, suitable in vivo models are needed to detect appropriate pathological consequences.

It has to be noted that heme, as a free circulating molecule, is currently debated because of its substantial hydrophobicity, the high concentration of heme-binding plasma proteins and the lack of validated, reliable tests to measure the free heme levels in plasma in clinical settings $(5,108)$. It is still unknown what is the exact free heme concentration in the context of SCD and during DHTR. After Hx consumption, heme could bind to albumin but without providing heme internalization (109). Given its amount in the circulation $(1 \mathrm{~g} / \mathrm{L})$, albumin could keep heme away from other proteins and could neutralize its harmful properties. Nevertheless, only minor beneficial effects are provided in vitro by albumin regarding oxidative reaction (110) and complement activation (56). Moreover, a broad number of studies have depicted pro-inflammatory processes upon injection of heme or heme/albumin in WT and SCD mouse models, excluding such substantial inhibitory capacity of albumin, despite its high plasma content $(46,105,106,111,112)$. Finally, in vivo experimental settings where heme levels were increased in the circulation in relatively more-pathophysiologically relevant ways, i.e. by intravascular hemolysis or injection of aged RBC, revealed efficacy of hemopexin in preventing mortality (113) and complement activation (56). In the latter study, decrease of acute kidney injury markers in $\mathrm{C}^{-/-}$mice revealed the impact of complement activation on kidney injury during hemolysis. Therefore, understanding the role of cell free heme on tissue injury and the contribution of complement to this process remains a crucial issue for the discovery of new therapeutic targets.

\section{Complement activation on RBC microvesicles}


Generation of MVs, i.e., extracellular vesicles that are shed from the plasma membrane, constitutes an integral part of RBC homeostasis, but this process is exacerbated in pathological conditions such as SCD(114). Novel discoveries on MVs from RBC, their ability to disseminate into the bloodstream and to modulate inflammation and coagulation have opened up a new field of investigation. MVs derived from $\mathrm{RBC}$ from heathy donors activate complement in vitro $(52,56,115)$. Although their administration did not affect healthy WT mice, mice pre-treated with LPS experienced aggravated pulmonary leukocyte sequestration and peripheral blood leukopenia(115). This process was at least in part complement-mediated, since it was attenuated by C5aR deficiency. This complement activation on RBC MVs was in part mediated by the significant exposure of PS and PE, able to serve as platforms for alternative pathway (52). PS exposure was associated with vaso-occlusion crisis in SCD mouse model of injection of RBC MVs, since pre-treatment with Annexin V prevented this phenotype $(44,45)$. Moreover, the authors described that RBC MVs from SCD patients contained 3-4 times more heme compare to MVs from healthy donors, making them a first-choice vehicle for heme. This propensity to carry and disseminate heme has been linked to a major role in vaso-occlusion crisis, as shown by a reduced bloodflow in renal arteries in SCD mouse injected with RBC MVs from SCD patients that was corrected by pre-administration of $\mathrm{Hx}$ (45). Recently, our study has demonstrated the critical impact of these natural heme-carriers on complement activation in vitro in serum and on endotheli cells (56). Indeed, SCD RBC MVs triggered stronger complement activation compared to healthy donors' RBC MVs. Hx only partially decreased complement activation (56), in agreement with the complement-activating propensity of PS and PE (52). Moreover, incubation of SCD MVs with endothelial cells caused greater loss of monolayer integrity, apoptotic activation, heme oxygenase-1 induction, and concomitant bioenergetic imbalance compared with control MVs(116). Altogether, these observations point towards a critical role of RBC MVs in the pathophysiological process of vaso-occlusion crisis, promoting complement activation in SCD.

\section{Conclusion: clinical relevance and therapeutic implications}

Taken together, the historical and recent in vitro and in vivo investigations support the critical impact of hemolysis breakdown products on complement activation in the context of SCD. The ensemble of these phenomena can explain the elevated complement activation fragments observed in plasma (4850, 117-119) and C3 deposits detected within kidneys $(53,56)$ from SCD patients. Experimental evidences in vitro and in mouse models of SCD show that complement blockade provides benefit (56, 57), pointing towards potential use of complement inhibitors in the clinic.

With regard to DHTRs, anti-complement therapies appear to be even more promising and the pioneering clinical experience is already available $(78,80,82,83)$, Table 1 . The main issue in DHTRs is that, despite an extended antibody screening and a cross-match, the evanescent antibodies might be 
undetectable before transfusion, especially in occasionally-transfused patients (120-122). Moreover, in some DHTRs, no antibodies are detectable whatsoever (72). The current management of DHTR (123) consists of supportive care alone in around half of cases (69) or with adjunctive measures, including recombinant erythropoietin and sometimes rituximab and/or IVIg therapy $(80,83,124)$ and/or plasma exchanges $(78,125,126)$ and/or other immunosuppression $(70,78)$. Additional transfusions might be ineffective or might increase hemolysis. Nevertheless, despite all of these treatments, the clinical condition might deteriorate, especially in the case of ongoing hyperhemolysis, leading to organ failure and subsequent life-threatening complications. Thus, prevention of DHTR is challenging and efficient therapeutic strategies are needed.

Blocking the effects of both IgG-mediated classical pathway activation and the alternative pathway activation via anti-complement therapies might allow to control the downstream reactions, causing RBC destruction or tissue injuries. The only clinically available complement blocker is the monoclonal antibody Eculizumab, which prevents the cleavage of C5 to C5a and C5b, and hence the generation of the anaphylatoxin C5a and the membrane attack complex C5b-9 (127). It has demonstrated remarkable efficacy in the treatment of patients with paroxysmal nocturnal hemoglobinuria (128) and atypical hemolytic uremic syndrome(129). Thus, Eculizumab might become the salvage therapy for severe DHTR cases, where it will cause a complete C5 blockade, as seen in several recent observations $(78,80,82,83)$. Moreover, if proven efficient in a larger series, it could be used not only as a salvage therapy but as a first-line therapy, especially in antibody-negative DHTR.

Regarding preventive treatment, rituximab has been recently used with success in hyperimmunized patients considered to be at high risk of developing DHTRs $(73,130,131)$. A potential role of prophylactic Eculizumab needs to be assessed, in particular in patients with recurrent antibodynegative DHTR.

Many questions remain to be answered in order to introduce complement blockers in the treatment of DHTR. First it is necessary to identify biomarkers allowing to select the patients who might benefit from anti-complement therapy. Soluble C5b-9 in plasma was increased in the few reported cases, which benefited from Eculizumab $(78,80,83)$, Table 1. A larger scale study is necessary to determine the sC5b-9 levels in patients with hyperhemolysis and with DHTR and to determine whether it could be an indicator for potential complement blocker therapy. The normal sC5b-9 levels do not preclude the use of complement inhibitors. Indeed, in patients with aHUS the activation of complement is local, on glomerular endothelium and does not necessarily induce increase in sC5b-9 in the circulation(62). In conclusion, complement blockade is holding promises but future prospective studies are required to introduce Eculizumab or another upcoming complement therapeutic (132) as a 
first- or second-line therapy, in particular for analyzing dosage, regimen, cost and side effects, as well as for exploring its potential prophylactic use.

\section{References}

1. Rother RP, Bell L, Hillmen P, Gladwin MT. The clinical sequelae of intravascular hemolysis and extracellular plasma hemoglobin: a novel mechanism of human disease. Jama. 2005;293(13):1653-62.

2. Tolosano E, Fagoonee S, Hirsch E, Berger FG, Baumann H, Silengo L, et al. Enhanced splenomegaly and severe liver inflammation in haptoglobin/hemopexin double-null mice after acute hemolysis. Blood. 2002;100(12):4201-8.

3. Lim SK, Ferraro B, Moore K, Halliwell B. Role of haptoglobin in free hemoglobin metabolism. Redox Rep. 2001;6(4):219-27.

4. Soares MP, Bozza MT. Red alert: labile heme is an alarmin. Curr Opin Immunol. 2016;38:94100.

5. Roumenina LT, Rayes J, Lacroix-Desmazes S, Dimitrov JD. Heme: Modulator of Plasma Systems in Hemolytic Diseases. Trends Mol Med. 2016;22(3):200-13.

6. Schaer DJ, Buehler PW, Alayash AI, Belcher JD, Vercellotti GM. Hemolysis and free hemoglobin revisited: exploring hemoglobin and hemin scavengers as a novel class of therapeutic proteins. Blood. 2013;121(8):1276-84.

7. Merle NS, Noe R, Halbwachs-Mecarelli L, Fremeaux-Bacchi V, Roumenina LT. Complement System Part II: Role in Immunity. Front Immunol. 2015;6:257.

8. Merle NS, Church SE, Fremeaux-Bacchi V, Roumenina LT. Complement System Part I Molecular Mechanisms of Activation and Regulation. Front Immunol. 2015;6:262.

9. Hajishengallis G, Reis ES, Mastellos DC, Ricklin D, Lambris JD. Novel mechanisms and functions of complement. Nat Immunol. 2017;18(12):1288-98.

10. Ricklin D, Hajishengallis G, Yang K, Lambris JD. Complement: a key system for immune surveillance and homeostasis. Nat Immunol. 2010;11(9):785-97.

11. Klos A, Tenner AJ, Johswich KO, Ager RR, Reis ES, Kohl J. The role of the anaphylatoxins in health and disease. Mol Immunol. 2009;46(14):2753-66.

12. Bubeck $D$. The making of a macromolecular machine: assembly of the membrane attack complex. Biochemistry. 2014;53(12):1908-15.

13. Schraufstatter IU, Khaldoyanidi SK, DiScipio RG. Complement activation in the context of stem cells and tissue repair. World J Stem Cells. 2015;7(8):1090-108.

14. Dempsey PW, Allison ME, Akkaraju S, Goodnow CC, Fearon DT. C3d of complement as a molecular adjuvant: bridging innate and acquired immunity. Science. 1996;271(5247):348-50.

15. Kaya Z, Afanasyeva M, Wang Y, Dohmen KM, Schlichting J, Tretter T, et al. Contribution of the innate immune system to autoimmune myocarditis: a role for complement. Nat Immunol. 2001;2(8):739-45.

16. Wiegner R, Chakraborty S, Huber-Lang M. Complement-coagulation crosstalk on cellular and artificial surfaces. Immunobiology. 2016;221(10):1073-9.

17. Gaboriaud C, Thielens NM, Gregory LA, Rossi V, Fontecilla-Camps JC, Arlaud GJ. Structure and activation of the $\mathrm{C} 1$ complex of complement: unraveling the puzzle. Trends Immunol. 2004;25(7):368-73.

18. Kishore U, Thielens NM, Gaboriaud C. Editorial: State-of-the-Art Research on C1q and the Classical Complement Pathway. Front Immunol. 2016;7:398.

19. Garred P, Genster N, Pilely K, Bayarri-Olmos R, Rosbjerg A, Ma YJ, et al. A journey through the lectin pathway of complement-MBL and beyond. Immunological reviews. 2016;274(1):74-97. 
20. Ricklin D, Reis ES, Mastellos DC, Gros P, Lambris JD. Complement component C3 - The "Swiss Army Knife" of innate immunity and host defense. Immunological reviews. 2016;274(1):33-58.

21. Hourcade DE. The role of properdin in the assembly of the alternative pathway C3 convertases of complement. J Biol Chem. 2006;281(4):2128-32.

22. Camous L, Roumenina L, Bigot $S$, Brachemi S, Fremeaux-Bacchi V, Lesavre $P$, et al. Complement alternative pathway acts as a positive feedback amplification of neutrophil activation. Blood. 2011;117(4):1340-9.

23. Del Conde I, Cruz MA, Zhang H, Lopez JA, Afshar-Kharghan V. Platelet activation leads to activation and propagation of the complement system. J Exp Med. 2005;201(6):871-9.

24. Morigi M, Galbusera M, Gastoldi S, Locatelli M, Buelli S, Pezzotta A, et al. Alternative pathway activation of complement by Shiga toxin promotes exuberant C3a formation that triggers microvascular thrombosis. J Immunol. 2011;187(1):172-80.

25. Schmidt CQ, Lambris JD, Ricklin D. Protection of host cells by complement regulators. Immunological reviews. 2016;274(1):152-71.

26. Xue X, Wu J, Ricklin D, Forneris F, Di Crescenzio P, Schmidt CQ, et al. Regulator-dependent mechanisms of C3b processing by factor I allow differentiation of immune responses. Nat Struct Mol Biol. 2017;24(8):643-51.

27. Weiler JM, Daha MR, Austen KF, Fearon DT. Control of the amplification convertase of complement by the plasma protein beta1H. Proc Natl Acad Sci U S A. 1976;73(9):3268-72.

28. Parente R, Clark SJ, Inforzato A, Day AJ. Complement factor $\mathrm{H}$ in host defense and immune evasion. Cell Mol Life Sci. 2017;74(9):1605-24.

29. Forneris F, Wu J, Xue X, Ricklin D, Lin Z, Sfyroera G, et al. Regulators of complement activity mediate inhibitory mechanisms through a common C3b-binding mode. Embo j. 2016;35(10):1133-

49.

30. Ricklin D, Reis ES, Lambris JD. Complement in disease: a defence system turning offensive. Nat Rev Nephrol. 2016;12(7):383-401.

31. Rosain J, Hong E, Fieschi C, Martins PV, El Sissy C, Deghmane AE, et al. Strains Responsible for Invasive Meningococcal Disease in Patients With Terminal Complement Pathway Deficiencies. J Infect Dis. 2017;215(8):1331-8.

32. Fakhouri F, Fremeaux-Bacchi V, Noel LH, Cook HT, Pickering MC. C3 glomerulopathy: a new classification. Nat Rev Nephrol. 2010;6(8):494-9.

33. Fakhouri F, Zuber J, Fremeaux-Bacchi V, Loirat C. Haemolytic uraemic syndrome. Lancet. 2017;390(10095):681-96.

34. Ling GS, Crawford G, Buang N, Bartok I, Tian K, Thielens NM, et al. C1q restrains autoimmunity and viral infection by regulating $\mathrm{CD} 8(+) \mathrm{T}$ cell metabolism. Science.

2018;360(6388):558-63.

35. Schonthaler HB, Guinea-Viniegra J, Wculek SK, Ruppen I, Ximenez-Embun P, Guio-Carrion A, et al. S100A8-S100A9 protein complex mediates psoriasis by regulating the expression of complement factor C3. Immunity. 2013;39(6):1171-81.

36. Angeletti A, Marasa M, Cravedi P. CD55 Deficiency and Protein-Losing Enteropathy. The New England journal of medicine. 377. United States2017. p. 1499.

37. Klemann C, Kirschner J, Ammann S, Urbach H, Moske-Eick O, Zieger B, et al. CD59 deficiency presenting as polyneuropathy and Moyamoya syndrome with endothelial abnormalities of small brain vessels. Eur J Paediatr Neurol. 2018;22(5):870-7.

38. van Lookeren Campagne M, Strauss EC, Yaspan BL. Age-related macular degeneration: Complement in action. Immunobiology. 2016;221(6):733-9.

39. Hong S, Beja-Glasser VF, Nfonoyim BM, Frouin A, Li S, Ramakrishnan S, et al. Complement and microglia mediate early synapse loss in Alzheimer mouse models. Science. 2016;352(6286):7126.

40. Afshar-Kharghan V. The role of the complement system in cancer. J Clin Invest. 2017;127(3):780-9. 
41. Ware RE, de Montalembert M, Tshilolo L, Abboud MR. Sickle cell disease. Lancet. 2017;390(10091):311-23.

42. Sundd P, Gladwin MT, Novelli EM. Pathophysiology of Sickle Cell Disease. Annu Rev Pathol. 2018.

43. Kato GJ, Steinberg MH, Gladwin MT. Intravascular hemolysis and the pathophysiology of sickle cell disease. J Clin Invest. 2017;127(3):750-60.

44. Camus SM, Gausseres B, Bonnin P, Loufrani L, Grimaud L, Charue D, et al. Erythrocyte microparticles can induce kidney vaso-occlusions in a murine model of sickle cell disease. Blood. 2012;120(25):5050-8.

45. Camus SM, De Moraes JA, Bonnin P, Abbyad P, Le Jeune S, Lionnet F, et al. Circulating cell membrane microparticles transfer heme to endothelial cells and trigger vasoocclusions in sickle cell disease. Blood. 2015;125(24):3805-14.

46. Belcher JD, Chen C, Nguyen J, Milbauer L, Abdulla F, Alayash Al, et al. Heme triggers TLR4 signaling leading to endothelial cell activation and vaso-occlusion in murine sickle cell disease. Blood. 2014;123(3):377-90.

47. deCiutiis AC, Peterson CM, Polley MJ, Metakis LJ. Alternative pathway activation in sickle cell disease and beta-thalassemia major. J Natl Med Assoc. 1978;70(7):503-6.

48. Chudwin DS, Papierniak C, Lint TF, Korenblit AD. Activation of the alternative complement pathway by red blood cells from patients with sickle cell disease. Clin Immunol Immunopathol. 1994;71(2):199-202.

49. Gavriilaki E, Mainou M, Christodoulou I, Koravou EE, Paleta A, Touloumenidou T, et al. In vitro evidence of complement activation in patients with sickle cell disease. Haematologica. 102. Italy2017. p. e481-e2.

50. Chapin J, Terry HS, Kleinert D, Laurence J. The role of complement activation in thrombosis and hemolytic anemias. Transfus Apher Sci. 2016;54(2):191-8.

51. Lombardi E, Matte A, Risitano AM, Ricklin D, Lambris JD, De Zanet D, et al. Factor H interfers with the adhesion of sickle red cells to vascular endothelium: a novel disease modulating molecule. Haematologica. 2019.

52. Wang RH, Phillips G, Jr., Medof ME, Mold C. Activation of the alternative complement pathway by exposure of phosphatidylethanolamine and phosphatidylserine on erythrocytes from sickle cell disease patients. J Clin Invest. 1993;92(3):1326-35.

53. Strauss J, Pardo V, Koss MN, Griswold W, McIntosh RM. Nephropathy associated with sickle cell anemia: an autologous immune complex nephritis. I. Studies on nature of glomerular-bound antibody and antigen identification in a patient with sickle cell disease and immune deposit glomerulonephritis. Am J Med. 1975;58(3):382-7.

54. Pardo V, Strauss J, Kramer H, Ozawa T, McIntosh RM. Nephropathy associated with sickle cell anemia: an autologous immune complex nephritis. II. Clinicopathologic study of seven patients. Am J Med. 1975;59(5):650-9.

55. De Paepe ME, Trudel M. The transgenic SAD mouse: a model of human sickle cell glomerulopathy. Kidney Int. 1994;46(5):1337-45.

56. Merle NS, Grunenwald A, Rajaratnam H, Gnemmi V, Frimat M, Figueres ML, et al. Intravascular hemolysis activates complement via cell-free heme and heme-loaded microvesicles. $\mathrm{JCl}$ Insight. 2018;3(12).

57. Vercellotti GM, Dalmasso AP, Schaid TR, Jr., Nguyen J, Chen C, Ericson ME, et al. Critical role of $\mathrm{C} 5 \mathrm{a}$ in sickle cell disease. Am J Hematol. 2018.

58. Frimat M, Tabarin F, Dimitrov JD, Poitou C, Halbwachs-Mecarelli L, Fremeaux-Bacchi V, et al. Complement activation by heme as a secondary hit for atypical hemolytic uremic syndrome. Blood. 2013;122(2):282-92.

59. May O, Merle NS, Grunenwald A, Gnemmi V, Leon J, Payet C, et al. Heme Drives Susceptibility of Glomerular Endothelium to Complement Overactivation Due to Inefficient Upregulation of Heme Oxygenase-1. Frontiers in Immunology. 2018;9(3008). 
60. Merle NS, Paule R, Leon J, Daugan M, Robe-Rybkine T, Poillerat V, et al. P-selectin drives complement attack on endothelium during intravascular hemolysis in TLR-4/heme-dependent manner. PNAS. 2019(in press).

61. Pawluczkowycz AW, Lindorfer MA, Waitumbi JN, Taylor RP. Hematin promotes complement alternative pathway-mediated deposition of $\mathrm{C} 3$ activation fragments on human erythrocytes: potential implications for the pathogenesis of anemia in malaria. J Immunol. 2007;179(8):5543-52. 62. Jourde-Chiche N, Fakhouri F, Dou L, Bellien J, Burtey S, Frimat M, et al. Endothelium structure and function in kidney health and disease. Nat Rev Nephrol. 2019.

63. Roumenina LT, Rayes J, Frimat M, Fremeaux-Bacchi V. Endothelial cells: source, barrier, and target of defensive mediators. Immunological reviews. 2016;274(1):307-29.

64. Pineda AA, Brzica SM, Jr., Taswell HF. Hemolytic transfusion reaction. Recent experience in a large blood bank. Mayo Clin Proc. 1978;53(6):378-90.

65. Josephson CD, Su LL, Hillyer KL, Hillyer CD. Transfusion in the patient with sickle cell disease: a critical review of the literature and transfusion guidelines. Transfus Med Rev. 2007;21(2):118-33.

66. Yazdanbakhsh K. Mechanisms of sickle cell alloimmunization. Transfus Clin Biol. 2015;22(3):178-81.

67. Nickel RS, Horan JT, Fasano RM, Meyer E, Josephson CD, Winkler AM, et al. Immunophenotypic parameters and RBC alloimmunization in children with sickle cell disease on chronic transfusion. Am J Hematol. 2015;90(12):1135-41.

68. Harm SK, Yazer MH, Monis GF, Triulzi DJ, Aubuchon JP, Delaney M. A centralized recipient database enhances the serologic safety of RBC transfusions for patients with sickle cell disease. Am J Clin Pathol. 2014;141(2):256-61.

69. Habibi A, Mekontso-Dessap A, Guillaud C, Michel M, Razazi K, Khellaf M, et al. Delayed hemolytic transfusion reaction in adult sickle-cell disease: presentations, outcomes, and treatments of 99 referral center episodes. Am J Hematol. 2016;91(10):989-94.

70. Vidler JB, Gardner K, Amenyah K, Mijovic A, Thein SL. Delayed haemolytic transfusion reaction in adults with sickle cell disease: a 5-year experience. Br J Haematol. 2015;169(5):746-53.

71. Narbey D, Habibi A, Chadebech P, Mekontso-Dessap A, Khellaf M, Lelievre JD, et al. Incidence and predictive score for delayed hemolytic transfusion reaction in adult patients with sickle cell disease. Am J Hematol. 2017;92(12):1340-8.

72. Talano JA, Hillery CA, Gottschall JL, Baylerian DM, Scott JP. Delayed hemolytic transfusion reaction/hyperhemolysis syndrome in children with sickle cell disease. Pediatrics. 2003;111(6 Pt 1):e661-5.

73. Pirenne F, Yazdanbakhsh K. How I safely transfuse patients with sickle-cell disease and manage delayed hemolytic transfusion reactions. Blood. 2018;131(25):2773-81.

74. Danaee A, Inusa B, Howard J, Robinson S. Hyperhemolysis in Patients With Hemoglobinopathies: A Single-Center Experience and Review of the Literature. Transfus Med Rev. 2015;29(4):220-30.

75. Adisa OA, Hu Y, Ghosh S, Aryee D, Osunkwo I, Ofori-Acquah SF. Association between plasma free haem and incidence of vaso-occlusive episodes and acute chest syndrome in children with sickle cell disease. Br J Haematol. 2013;162(5):702-5.

76. Garratty G. Severe reactions associated with transfusion of patients with sickle cell disease. Transfusion. 1997;37(4):357-61.

77. Stowell SR, Winkler AM, Maier CL, Arthur CM, Smith NH, Girard-Pierce KR, et al. Initiation and regulation of complement during hemolytic transfusion reactions. Clin Dev Immunol. 2012;2012:307093.

78. Dumas G, Habibi A, Onimus T, Merle JC, Razazi K, Mekontso Dessap A, et al. Eculizumab salvage therapy for delayed hemolysis transfusion reaction in sickle cell disease patients. Blood. 127. United States2016. p. 1062-4. 
79. Chonat S, Chandrakasan S, Kalinyak KA, Ingala D, Gruppo R, Kalfa TA. Atypical haemolytic uraemic syndrome in a patient with sickle cell disease, successfully treated with eculizumab. $\mathrm{Br} \mathrm{J}$ Haematol. 2016;175(4):744-7.

80. Chonat S, Quarmyne MO, Bennett CM, Dean CL, Joiner CH, Fasano RM, et al. Contribution of alternative complement pathway to delayed hemolytic transfusion reaction in sickle cell disease. Haematologica. 103. Italy2018. p. e483-e5.

81. Salama A, Bhakdi S, Mueller-Eckhardt C. Evidence suggesting the occurrence of C3independent intravascular immune hemolysis. Reactive hemolysis in vivo. Transfusion. 1987;27(1):49-53.

82. Boonyasampant M, Weitz IC, Kay B, Boonchalermvichian C, Liebman HA, Shulman IA. Lifethreatening delayed hyperhemolytic transfusion reaction in a patient with sickle cell disease: effective treatment with eculizumab followed by rituximab. Transfusion. 2015;55(10):2398-403. 83. Vlachaki E, Gavriilaki E, Kafantari K, Adamidou D, Tsitsikas D, Chasapopoulou E, et al. Successful Outcome of Hyperhemolysis in Sickle Cell Disease following Multiple Lines of Treatment: The Role of Complement Inhibition. Hemoglobin. 2019:1-3.

84. Hadzhieva M, Pashov AD, Kaveri S, Lacroix-Desmazes S, Mouquet H, Dimitrov JD. Impact of Antigen Density on the Binding Mechanism of IgG Antibodies. Sci Rep. 2017;7(1):3767.

85. Dimitrov JD, Kaveri SV, Lacroix-Desmazes S. Thermodynamic stability contributes to immunoglobulin specificity. Trends Biochem Sci. 2014;39(5):221-6.

86. Dimitrov JD, Planchais C, Roumenina LT, Vassilev TL, Kaveri SV, Lacroix-Desmazes S. Antibody polyreactivity in health and disease: statu variabilis. J Immunol. 2013;191(3):993-9.

87. Dimitrov JD, Roumenina LT, Doltchinkova VR, Mihaylova NM, Lacroix-Desmazes S, Kaveri SV, et al. Antibodies use heme as a cofactor to extend their pathogen elimination activity and to acquire new effector functions. J Biol Chem. 2007;282(37):26696-706.

88. Dimitrov JD, Ivanovska ND, Lacroix-Desmazes S, Doltchinkova VR, Kaveri SV, Vassilev TL. Ferrous ions and reactive oxygen species increase antigen-binding and anti-inflammatory activities of immunoglobulin G. J Biol Chem. 2006;281(1):439-46.

89. Dimitrov JD, Roumenina LT, Doltchinkova VR, Vassilev TL. Iron ions and haeme modulate the binding properties of complement subcomponent $\mathrm{C} 1 \mathrm{q}$ and of immunoglobulins. Scand J Immunol. 2007;65(3):230-9.

90. Kanyavuz A, Marey-Jarossay A, Lacroix-Desmazes S, Dimitrov JD. Breaking the law: unconventional strategies for antibody diversification. Nature reviews Immunology. 2019.

91. Diebolder CA, Beurskens FJ, de Jong RN, Koning RI, Strumane K, Lindorfer MA, et al. Complement is activated by IgG hexamers assembled at the cell surface. Science.

2014;343(6176):1260-3.

92. Ugurlar D, Howes SC, de Kreuk BJ, Koning RI, de Jong RN, Beurskens FJ, et al. Structures of C1-lgG1 provide insights into how danger pattern recognition activates complement. Science. 2018;359(6377):794-7.

93. Desmarets $M$, Noizat-Pirenne F. [Murine models in blood transfusion: allo-immunization, hemolysis]. Transfus Clin Biol. 2011;18(2):115-23.

94. Schirmer DA, Song SC, Baliff JP, Harbers SO, Clynes RA, Krop-Watorek A, et al. Mouse models of IgG- and IgM-mediated hemolysis. Blood. 2007;109(7):3099-107.

95. Hendrickson JE, Desmarets M, Deshpande SS, Chadwick TE, Hillyer CD, Roback JD, et al. Recipient inflammation affects the frequency and magnitude of immunization to transfused red blood cells. Transfusion. 2006;46(9):1526-36.

96. Desmarets M, Cadwell CM, Peterson KR, Neades R, Zimring JC. Minor histocompatibility antigens on transfused leukoreduced units of red blood cells induce bone marrow transplant rejection in a mouse model. Blood. 2009;114(11):2315-22.

97. Elayeb R, Tamagne M, Pinheiro M, Ripa J, Djoudi R, Bierling P, et al. Anti-CD20 Antibody Prevents Red Blood Cell Alloimmunization in a Mouse Model. J Immunol. 2017;199(11):3771-80. 
98. Hod EA, Zimring JC, Spitalnik SL. Lessons learned from mouse models of hemolytic transfusion reactions. Curr Opin Hematol. 2008;15(6):601-5.

99. Girard-Pierce KR, Stowell SR, Smith NH, Arthur CM, Sullivan HC, Hendrickson JE, et al. A novel role for $\mathrm{C} 3$ in antibody-induced red blood cell clearance and antigen modulation. Blood.

2013;122(10):1793-801.

100. Test ST, Woolworth VS. Defective regulation of complement by the sickle erythrocyte: evidence for a defect in control of membrane attack complex formation. Blood. 1994;83(3):842-52. 101. Roumenina LT, Radanova M, Atanasov BP, Popov KT, Kaveri SV, Lacroix-Desmazes S, et al. Heme interacts with $\mathrm{c} 1 \mathrm{q}$ and inhibits the classical complement pathway. J Biol Chem. 2011;286(18):16459-69.

102. Lindorfer MA, Cook EM, Reis ES, Ricklin D, Risitano AM, Lambris JD, et al. Compstatin Cp40 blocks hematin-mediated deposition of C3b fragments on erythrocytes: Implications for treatment of malarial anemia. Clin Immunol. 2016;171:32-5.

103. Figueiredo RT, Fernandez PL, Mourao-Sa DS, Porto BN, Dutra FF, Alves LS, et al. Characterization of heme as activator of Toll-like receptor 4. J Biol Chem. 2007;282(28):20221-9.

104. Piazza M, Colombo M, Zanoni I, Granucci F, Tortora P, Weiss J, et al. Uniform lipopolysaccharide (LPS)-loaded magnetic nanoparticles for the investigation of LPS-TLR4 signaling. Angew Chem Int Ed Engl. 2011;50(3):622-6.

105. Vinchi F, Costa da Silva M, Ingoglia G, Petrillo S, Brinkman N, Zuercher A, et al. Hemopexin therapy reverts heme-induced proinflammatory phenotypic switching of macrophages in a mouse model of sickle cell disease. Blood. 2016;127(4):473-86.

106. Merle NS, Grunenwald A, Figueres ML, Chauvet S, Daugan M, Knockaert S, et al. Characterization of Renal Injury and Inflammation in an Experimental Model of Intravascular Hemolysis. Front Immunol. 2018;9:179.

107. Ataga KI, Kutlar A, Kanter J, Liles D, Cancado R, Friedrisch J, et al. Crizanlizumab for the Prevention of Pain Crises in Sickle Cell Disease. The New England journal of medicine.

2017;376(5):429-39.

108. Vallelian F, Schaer CA, Deuel JW, Ingoglia G, Humar R, Buehler PW, et al. Revisiting the putative role of heme as a trigger of inflammation. Pharmacol Res Perspect. 2018;6(2):e00392. 109. Schaer DJ, Vinchi F, Ingoglia G, Tolosano E, Buehler PW. Haptoglobin, hemopexin, and related defense pathways-basic science, clinical perspectives, and drug development. Front Physiol. 2014;5:415.

110. Deuel JW, Vallelian F, Schaer CA, Puglia M, Buehler PW, Schaer DJ. Different target specificities of haptoglobin and hemopexin define a sequential protection system against vascular hemoglobin toxicity. Free Radic Biol Med. 2015;89:931-43.

111. Vinchi F, De Franceschi L, Ghigo A, Townes T, Cimino J, Silengo L, et al. Hemopexin therapy improves cardiovascular function by preventing heme-induced endothelial toxicity in mouse models of hemolytic diseases. Circulation. 2013;127(12):1317-29.

112. Ingoglia G, Sag CM, Rex N, De Franceschi L, Vinchi F, Cimino J, et al. Hemopexin counteracts systolic dysfunction induced by heme-driven oxidative stress. Free Radic Biol Med. 2017;108:452-64. 113. Graw JA, Mayeur C, Rosales I, Liu Y, Sabbisetti VS, Riley FE, et al. Haptoglobin or Hemopexin Therapy Prevents Acute Adverse Effects of Resuscitation After Prolonged Storage of Red Cells. Circulation. 2016;134(13):945-60.

114. Leal JKF, Adjobo-Hermans MJW, Bosman G. Red Blood Cell Homeostasis: Mechanisms and Effects of Microvesicle Generation in Health and Disease. Front Physiol. 2018;9:703.

115. Zecher D, Cumpelik A, Schifferli JA. Erythrocyte-derived microvesicles amplify systemic inflammation by thrombin-dependent activation of complement. Arterioscler Thromb Vasc Biol. 2014;34(2):313-20.

116. Jana S, Strader MB, Meng F, Hicks W, Kassa T, Tarandovskiy I, et al. Hemoglobin oxidationdependent reactions promote interactions with band 3 and oxidative changes in sickle cell-derived microparticles. JCl Insight. 2018;3(21). 
117. Mold C, Tamerius JD, Phillips G, Jr. Complement activation during painful crisis in sickle cell anemia. Clin Immunol Immunopathol. 1995;76(3 Pt 1):314-20.

118. Koethe SM, Casper JT, Rodey GE. Alternative complement pathway activity in sera from patients with sickle cell disease. Clin Exp Immunol. 1976;23(1):56-60.

119. Chudwin DS, Korenblit AD, Kingzette M, Artrip S, Rao S. Increased activation of the alternative complement pathway in sickle cell disease. Clin Immunol Immunopathol. 1985;37(1):937.

120. Michot JM, Driss F, Guitton C, Moh Klaren J, Lefebvre F, Chamillard X, et al. Immunohematologic tolerance of chronic transfusion exchanges with erythrocytapheresis in sickle cell disease. Transfusion. 2015;55(2):357-63.

121. Castro O, Oneal P, Medina A, Onojobi G, Gordeuk VR. Preventing delayed hemolytic transfusion reactions in sickle cell disease. Transfusion. 2016;56(11):2899-900.

122. Schonewille $H$, Honohan A, van der Watering LM, Hudig F, Te Boekhorst PA, Koopman-van Gemert AW, et al. Incidence of alloantibody formation after ABO-D or extended matched red blood cell transfusions: a randomized trial (MATCH study). Transfusion. 2016;56(2):311-20.

123. Pirenne F, Bartolucci P, Habibi A. Management of delayed hemolytic transfusion reaction in sickle cell disease: Prevention, diagnosis, treatment. Transfus Clin Biol. 2017;24(3):227-31.

124. Win N, Needs M, Thornton N, Webster R, Chang C. Transfusions of least-incompatible blood with intravenous immunoglobulin plus steroids cover in two patients with rare antibody.

Transfusion. 2018;58(7):1626-30.

125. Hayes $\mathrm{C}$, Shafi $\mathrm{H}$, Mason H, Klapper E. Successful reduction of plasma free-hemoglobin using therapeutic plasma exchange: A case report. Transfus Apher Sci. 2016;54(2):253-5.

126. Louie JE, Anderson CJ, Fayaz MFK, Henry A, Killeen T, Mohandas N, et al. Case series supporting heme detoxification via therapeutic plasma exchange in acute multiorgan failure syndrome resistant to red blood cell exchange in sickle cell disease. Transfusion. 2018;58(2):470-9.

127. Parker CJ, Kar S, Kirkpatrick P. Eculizumab. Nat Rev Drug Discov. 2007;6(7):515-6.

128. Hillmen P, Young NS, Schubert J, Brodsky RA, Socie G, Muus P, et al. The complement inhibitor eculizumab in paroxysmal nocturnal hemoglobinuria. The New England journal of medicine. 2006;355(12):1233-43.

129. Legendre CM, Licht C, Muus P, Greenbaum LA, Babu S, Bedrosian C, et al. Terminal complement inhibitor eculizumab in atypical hemolytic-uremic syndrome. The New England journal of medicine. 2013;368(23):2169-81.

130. Bachmeyer C, Maury J, Parrot A, Bachir D, Stankovic K, Girot R, et al. Rituximab as an effective treatment of hyperhemolysis syndrome in sickle cell anemia. Am J Hematol. 2010;85(1):912.

131. Noizat-Pirenne F, Habibi A, Mekontso-Dessap A, Razazi K, Chadebech P, Mahevas M, et al. The use of rituximab to prevent severe delayed haemolytic transfusion reaction in immunized patients with sickle cell disease. Vox Sang. 2015;108(3):262-7.

132. Ricklin D, Mastellos DC, Reis ES, Lambris JD. The renaissance of complement therapeutics. Nat Rev Nephrol. 2018;14(1):26-47.

133. Gupta S, Fenves A, Nance ST, Sykes DB, Dzik WS. Hyperhemolysis syndrome in a patient without a hemoglobinopathy, unresponsive to treatment with eculizumab. Transfusion. 2015;55(3):623-8.

134. Weinstock C, Mohle R, Dorn C, Weisel K, Hochsmann B, Schrezenmeier H, et al. Successful use of eculizumab for treatment of an acute hemolytic reaction after $\mathrm{ABO}$-incompatible red blood cell transfusion. Transfusion. 2015;55(3):605-10. 
Table 1. Cases of hemolytic transfusion reactions treated with Eculizumab.

\begin{tabular}{|c|c|c|c|c|c|c|c|}
\hline References & SCD & $\begin{array}{l}\text { C3 } \\
\text { level } \\
\text { (mg/L) }\end{array}$ & $\begin{array}{l}\text { C4 } \\
\text { level } \\
\text { (mg/L) }\end{array}$ & $\begin{array}{l}\text { C5b9 } \\
\text { level } \\
\text { (ng/ml) }\end{array}$ & $\begin{array}{l}\text { Associated } \\
\text { treatments }\end{array}$ & Delay $^{a}$ & $\begin{array}{l}\text { Outcome }^{b} \text { after } \\
\text { Eculizumab therapy }\end{array}$ \\
\hline $\begin{array}{l}\text { Gupta et al } \\
(2014)(133)\end{array}$ & No & I & / & I & None & 17 days & No effect \\
\hline $\begin{array}{l}\text { Weinstock et } \\
\text { al (2015) (134) }\end{array}$ & $\mathrm{No}^{\mathrm{C}}$ & / & I & / & $\begin{array}{l}\text { CS \& } \\
\text { Heparin } \\
\text { infusion }\end{array}$ & 1 hour & $\begin{array}{l}\text { Improvement from } \\
\text { day } 2\end{array}$ \\
\hline $\begin{array}{c}\text { Boonyasampat } \\
\text { et al } \\
(2015)(82)\end{array}$ & Yes & / & / & / & Rituximab & 3 days & $\begin{array}{l}\text { Improvment from } \\
\text { day } 7\end{array}$ \\
\hline \multirow{3}{*}{$\begin{array}{c}\text { Dumas et al } \\
\text { (2016) } \\
\text { (78) }\end{array}$} & $\begin{array}{l}\text { Patient } \\
1: \text { Yes }\end{array}$ & 1080 & 266 & 856 & None & 7 days & $\begin{array}{l}\text { Improvement from } \\
\text { day } 3\end{array}$ \\
\hline & $\begin{array}{l}\text { Patient } \\
2: \text { Yes }\end{array}$ & / & I & I & PLEX & 7 days & $\begin{array}{l}\text { Improvement from } \\
\text { day } 21\end{array}$ \\
\hline & $\begin{array}{l}\text { Patient } \\
3: \text { Yes }\end{array}$ & 313 & 104 & 1527 & IS \& CS & 9 days & $\begin{array}{l}\text { Improvement from } \\
\text { day } 1\end{array}$ \\
\hline $\begin{array}{l}\text { Chonat et al } \\
(2018)(80)\end{array}$ & Yes & 1350 & 214 & 270 & $\begin{array}{l}\text { CS, Ivlg \& } \\
\text { Rituximab }\end{array}$ & 14 days & $\begin{array}{l}\text { Improvement from } \\
\text { day } 2\end{array}$ \\
\hline $\begin{array}{l}\text { Vlachaki et al } \\
(2019)(83)\end{array}$ & Yes & / & I & 325 & $\begin{array}{l}\text { CS, Ivlg \& } \\
\text { Rituximab }\end{array}$ & 10 days & $\begin{array}{l}\text { Improvement from } \\
\text { day } 3\end{array}$ \\
\hline
\end{tabular}

C3 : C3 complement component (normal range, $660-1500 \mathrm{mg} / \mathrm{L}$ ) ; C4 : C4 complement component (normal range, 93-380 mg/L); SC5B9 : soluble terminal complement complex (normal range <244 $\mathrm{ng} / \mathrm{mL}$ ) ; SCD: sickle cell disease; HTR : Hemolytic Transfusion Reaction; PLEX : Plasma Exchange ; CS : corticosteroids; IS : immunosuppressive regimen ; Ivlg : intravenous human polyvalent immunoglobulins. ${ }^{\mathrm{a}}$ Delay from RBC transfusion to Eculizumab therapy; ${ }^{\mathrm{b}}$ Eculizumab therapy was considered successful since it allowed hemoglobin stabilization and a decrease in hemolysis markers (LDH and/or free bilirubin); ${ }^{\mathrm{C}}$ Acute hemolytic reaction was due to $\mathrm{ABO}$-incompatible red blood cell transfusion

Figures legends

\section{Figure 1: The complement system}

Complement system is composed of three different pathways. Classical pathway is activated by immune complex (IC) formation on pathogen surface and by different ligands, expressed on apoptotic cells, leading to $\mathrm{C} 1$ complex association. Lectin pathway recognizes mannose-terminal glycans on pathogens leading to MBL MASP complex activation. Both induce formation of the classical C3 convertase $\mathrm{C} 4 \mathrm{~b} 2 \mathrm{a}$. Alternative pathway is permanently activated at low level by spontaneous hydrolysis of $\mathrm{C} 3$ into $\mathrm{C} 3\left(\mathrm{H}_{2} \mathrm{O}\right)$. Lack of complement inhibitors on pathogens promotes alternative $\mathrm{C} 3$ convertase $\mathrm{C} 3 \mathrm{bBb}$ formation. Complement activation leads to opsonization and phagocytosis by $\mathrm{C} 3 \mathrm{~b}$ deposition and bacterial lysis by $\mathrm{C} 5 \mathrm{~b}-9$ complex formation. The production of anaphylatoxins $\mathrm{C} 3 \mathrm{a}$ and C5a leads to inflammation, recruitment of immune cells, activation of endothelial, epithelial cells, and platelets. Under physiological conditions, activation of the complement system is tightly 
regulated by plasmatic regulators such as $\mathrm{FI}, \mathrm{FH}, \mathrm{Clinh}$ or $\mathrm{C} 4 \mathrm{BP}$, while membrane regulation is ensured by MCP, DAF, CD59 or CR1 as well as by FH, bound to cell surface.

\section{Figure 2: The classical complement pathway and DHTR}

Complement fixing IgG antibodies against alloantigens on transfused red blood cells (RBC) can mediate DHTR through recruitment of the $\mathrm{C} 1$ complex $(\mathrm{C} 1 \mathrm{qC} 1 \mathrm{r} 2 \mathrm{C} 1 \mathrm{~s} 2)$ of the classical pathway and further $\mathrm{C} 3 \mathrm{~b}$ deposits on $\mathrm{RBC}$ membranes. If complement activation is incomplete, it results in opsonization with $\mathrm{C} 3$ activation fragments and extravascular hemolysis, i.e. phagocytosis (a). However, if complement activation is complete, it induces membrane attack complex formation and direct intravascular hemolysis, leading to release of cell-free $\mathrm{Hb}$ and heme into the circulation (b). Conversely, non-complement binding IgG mediate RBC destruction through the extravascular reticuloendothelial system (not shown).

\section{Figure 3: Heme is an activator of the alternative complement pathway.}

In pathological conditions, such as in HTR, scavengers are overwhelmed by massive intravascular hemolysis, leading to release of cell-free heme in the circulation. Heme induces alternative complement pathway activation by promoting hydrolysis of $\mathrm{C} 3$ into $\mathrm{C} 3\left(\mathrm{H}_{2} \mathrm{O}\right)(1)$, formation of a fluid phase C3 convertase directly in serum (2) and leads to complement deposits on endothelial cells (3). Further activation of the complement system is increased by the "amplification loop" (4) and activation of EC by $\mathrm{C} 5 \mathrm{~b} 9$ formation (5). 